\title{
The Reality of Strategic Planning in the Faculties of Educational Sciences in Jordanian Private Universities, and Its Relation to Academic Excellence
}

\author{
Dr. Reda. S. Al-Mawdieh ${ }^{1}$ \\ ${ }^{1}$ Associate professor, The faculty of educational sciences, Zarqa University, Jordan \\ Correspondence: Dr. Reda. S. Al-Mawdieh, Associate professor, The faculty of educational sciences, Zarqa \\ University, Jordan.
}

Received: October 13, 2019

Accepted: February 17, 2020

Online Published: February 18, 2020

doi:10.5430/ijhe.v9n1p270

URL: https://doi.org/10.5430/ijhe.v9n1p270

\begin{abstract}
This study aimed at finding out the reality of strategic planning in the faculties of educational sciences in Jordanian private universities. A questionnaire was distributed to the study population of (84) faculty members. A total of (67) questionnaires were retrieved, seven of which were excluded. The results of analysis of the remaining (60) questionnaires indicated that the level of strategic planning in Jordanian private universities was high. Also, the level of achieving academic excellence in Jordanian private universities was high. Furthermore, there was a positive significant correlational relationship at $(\alpha \leq 0.05)$ between the level of the reality of strategic planning and the level of achieving academic excellence in Jordanian private universities. The recommendations of this study included providing rewards to distinguished teaching staff at Jordanian private universities and the commendation of their efforts.
\end{abstract}

Keywords: Strategic planning, academic excellence, Jordanian private universities

\section{Introduction}

There is no doubt that strategic planning plays a major role in the life of any institution, whether it was productive or educational, particularly as the world is witnessing developments in various fields of life. This puts all institutions encountering challenges. Including universities that face many challenges in light of this information revolution and rebirth in administration. Therefore, a mature organizational mentality is required so that universities have the ability to face these challenges in a scientific and administrative manner through enhancing administrative processes. Thus, strategic planning plays a vital role in these operations. This is why strategic planning has received a lot of attention from public bodies and educational institutions, including universities. Universities and their colleges are like any educational and productive institution in that they need to employ proper scientific planning and management with scientific and practical competence so that they can advance in their mission and achieve their goals.

For this reason, in 2010, the Erbil National Conference for the Reform of Higher Education and Scientific Research held in Erbil pointed to the need for each university and other institutions to develop a strategic plan to define a vision and a mission and set specific philosophical goals. The Conference also highlighted that the performance of universities and other related bodies needed to be examined in order to establish, measurable standards in the scientific, educational, administrative and service fields. It also indicated that a tendency towards decentralization and organizational and structural flexibility needed to be established, so that universities and other educational institutions were ready to respond to rapid and continuous change (Ministry of Higher Education and Scientific Research, 2010: 3).

Therefore, the faculties of educational sciences in Jordan have been striving to reach a state of excellence in all their activities and achieve unprecedented results compared to other educational institutions such as public colleges. For this reason, the interest of the educational science faculties in what is known as "the administration of academic excellence" has recently become apparent as they attempt to adapt to the new business environment and the competitiveness among the faculties of different universities. However, this goal of seeking to achieve excellence is not new, as it was recognized thousands of years ago by The Messenger of Allah, Mohammad (peace be upon him), in the Hadith " May God's mercy fall up on someone who has done a job and perfected it." Thus the Messenger of Mercy emphasized that excellence in the performance of work could be achieved through mastery (Al-Hilalat, 2014). 


\section{Study Problem and Questions}

The impact of the technology and communications revolution and its on-going rapid development and changes has created difficulties in the field of strategic planning. This is particularly the case in respect, of the ability of those responsible for predicting and looking at the future of educational institutions. There is also a lack of flexibility in the legislation that controls these institutions, as well as scarcity of financial resources. Thus, strategic planning has become an obsession and important for all peoples and institutions to match the requirements of the era. It is an indication of the evolution and maturity of administrative and strategic management. Based on this, strategic planning, particularly in the educational field demands more the future rational development of a vision for education coupled with specific goals and objectives. These goals and objectives need to be easy to achieve as quickly as possible with the least effort and cost. Hence a problem arises that can be formulated in the following question: What is the reality of strategic planning in the faculties of educational sciences in Jordanian private universities and its relation to academic excellence?

In light of the above, the following sub questions arise:

- What is the reality of strategic planning in the faculties of educational sciences in Jordanian private universities?

- What is the level of achieving academic excellence in Jordanian private universities?

- Is there a significant relationship at $(\alpha \leq 0.05)$ between the reality of strategic planning and academic excellence in the Jordanian private universities?

\section{Objectives of the Study}

This study aims to achieve the following objectives:

- To determine the reality of strategic planning in the faculties of educational sciences in Jordanian private universities;

- To determine the level of achievement of academic excellence in Jordanian private universities;

- To highlight the relationship between strategic planning and academic excellence in Jordanian private universities.

\section{Importance of the Study}

Based on foregoing, the importance of the study can be summarized by the following points:

- Strategic planning has an important and vital role in shaping the future vision of faculties of educational sciences.

- This study could be a catalyst for further research on strategic planning in other faculties.

- It is hoped that this study will contribute to the improvement of the performance of faculty staff and help them to not only maintain their performance, but also develop it for the better.

- The results of this study may benefit decision makers in university administrations, the accreditation body of higher education institutions and the directors of centres of quality assurance and accreditation in universities in their endeavours to achieve continuous improvements in educational institutions.

- This study may benefit those working in the strategic planning of the faculties of education by showing them strengths and weaknesses.

\section{Previous Studies}

Prior to undertaking the survey and analysis, this study reviewed previous relevant studies. These studies are discussed below in ascending chronological order.

Shablaq (2006) conducted a study aimed at revealing the role of the school development program in the development of planning skills among secondary school principals in Gaza governorate. The analytical descriptive methodology was used as it was best suited to the subject of the study. The sample consisted of (85) principals. A questionnaire tool was used to collect data. The findings showed that the school development program was successful in developing principals' planning skills. The program also achieved the highest levels of development in school planning skills in the field of vision formulation and goal setting. The results also showed that there were no significant differences in the level of development of planning skills among school principals according to sex, academic qualifications, and years of service. 
Killen and Walker's (2007) study aimed at highlighting the benefits of using a strategic quality functions system for strategic planning. The analytical descriptive methodology was used as well as three case studies. The study concluded that using this quality functions avoided analysis of the complexity matrix led to moving directly to the concept of evaluation and timing. The study found that the most important benefit of this system was the level of commitment and support for the outputs of the strategy throughout the organization.But the practical effects will impact planners and strategists and teach them that the methods and philosophy of the system based on quality functions are useful tools to find a general strategy. The study also provided in-depth knowledge to participants and academics on how the strategic quality functions system can translate a vision into actions, defines purpose, and create a consistent creative strategy even in rapidly changing environments.

Dajani (2006) study aimed at finding out the reality of strategic planning at the Islamic University in Gaza. The descriptive methodology was used. A content analysis card and questionnaire were used as the study tools. In addition, a focus group workshop consisting of 10 professors from different colleges was convened to analyse the content of the strategic plan. The study concluded that it was important to clarify the general concept of strategic planning being followed by the administration and also to ensure that the standards of the National Commission for Accreditation and Quality were applied in the components of the strategic plan of the university.

Al- shuwaikh( 2007) study aimed at identifying the reality of strategic planning in technical education intuitions in the governorates of Gaza. The analytical descriptive methodology was used. A questionnaire consisting of (60) items was designed and distributed to the study population, which consisted of deans, their deputies and heads of departments, during the academic year 2006/2007. One of the most important findings of the study was that there is a relationship between strategic planning in technical education institutions and the extent to which college management is committed to strategic planning.

Defifo( 2008) study aimed at investigating the strategic planning process and its role in building trust in the decision making process. The study also sought to determine the role that should be played by the dean of the college in the process of change planning and the role of strategic planning in the development of the performance of institutions. The case study methodology was used. Individual interviews, focus groups, documents and e-mail were used in the data analysis. The target sample was selected from two higher education institutions in America, namely the Oceania and Cooper institutions. The study concluded that the strategic planning helps employees to understand their institution and its future direction. However, the efficacy of strategic planning depends on several factors. Firstly, trust between the director and the board of directors.Secondly, trust between management and employees.

The study conducted by Al-Sanei (2013) aimed at identifying the level of strategic planning practice of the deans of middle university colleges and their deputies, and its relationship with the level of quality assurance. The study population consisted of all Intermediate University Colleges of Al Balqa Applied University which are spread across the Hashemite Kingdom of Jordan, administratively, financially, academically and technically. In order to achieve the objectives of the study, three governorates were selectedfrom Intermediate University Colleges by purposive sampling. Consequently, the final study sample consisted of (47) deans and deputies. Two questionnaires were developed to collect the required data.Their validity and reliability were verified. The most important results obtained by the study were that the level of strategic planning practice of the deans of the Intermediate University Colleges in three governorates from the deans and their deputies' point of view was high.

Marzouga (2014) carried out a study aimed at identifying the impact of the dimensions of strategic planning (vision, mission, goals and timescale) on total quality management on improving the performance of employees in Jordanian private universities. The analytical descriptive methodology was used. The study population consisted of (19) universities. Four universities and 91 staff members form all administrative levels were selected by using the purposive sampling method. The most important finding of this study was that the level of strategic planning for total quality management in Jordanian private universities was high.

Abu Hassanah (2016) study aimed at determining the level of strategic planning skills and practice among the leaders of the faculties of education in Palestinian universities for the skills of strategic planning, and its relation to improving institutional performance from faculty members' point of view. The results were investigated to identify whether there were any significant differences according to the university, academic rank and academic year. The study population consisted of all faculty members in the faculties of education at the Islamic University, Al-Azhar University and Al-Aqsa University in the academic year (2013/2014). There number was (141) faculty members. Total of (121) questionnaires were retrieved. The main result reported by the study was that the level of approval of the sample regarding the level of strategic planning skills and practice among the leaders of faculties of education in Palestinian universities was high. 
Finally, in a recent study, Nabhani(2019) study aimed at identifying the reality of strategic planning and its relation with the level of educational performance in the Faculty of Applied Sciences in the Sultanate of Oman from the staff members' point of view. The final study sample consisted of 47 staff members. The findings showed that there was a positive relationship between strategic planning and the level of educational performance in the colleges and that there were positive attitudes toward the process of strategic planning among the faculty members.

\section{Study Methodology}

This study employed two scientific research methodologies:

Analytical descriptive research, which was used to cover the theoretical side of the study. It was used to review the most relevant literature related to the reality of strategic planning and academic excellence. It was also used to compare the results of this study with those of previous studies whenever possible.

Field research, which was used to cover the practical aspect of this study. It was used to collect and analyse the data obtained from the responses to a questionnaire designed for the purposes of this study, in accordance with recognized scientific steps.

\section{Study Population}

The study population consisted of staff members in the faculties of educational sciences at Jordanian private universities. At the time of the study there were (84) members distributed across six universities as shown in Table 1.

Table 1. Distribution of faculty members in Jordanian private universities

\begin{tabular}{cccccc}
\hline University & Professor & $\begin{array}{c}\text { Associate } \\
\text { Professor }\end{array}$ & $\begin{array}{c}\text { Assistant } \\
\text { Professor }\end{array}$ & Teacher & Total \\
\hline Al-Zarqa & 4 & 2 & 8 & 2 & 16 \\
Irbid National & 3 & 3 & 4 & - & 10 \\
Al-Isra & 2 & 2 & 7 & - & 11 \\
Middle East & 5 & 4 & 5 & - & 14 \\
Jerash & 4 & 5 & 1 & 1 & 11 \\
Petra & - & 4 & 16 & 2 & 22 \\
Total & 18 & 20 & 41 & 5 & 84 \\
\hline
\end{tabular}

Due to the small size of the study population, the population was the sample. Therefore, the questionnaire was distributed to all (84) members of the study population. A total of 67 questionnaires were retrieved. However, seven questionnaires were excluded due to their lack of validity for statistical analysis. Thus (60) questionnaires were analysed. Table 2 shows the distribution of the study sample according to demographic and functional variables.

Table 2. Distribution of study population according to (sex, years of experience and academic rank) variables

\begin{tabular}{ccccc}
\hline No. & Variable & Category & Number & Percentage \% \\
\hline \multirow{2}{*}{ Sex } & Male & 44 & 73.3 \\
& & Female & 16 & 26.7 \\
& & 5 years & 17 & 28.3 \\
& \multirow{2}{*}{ Years of experience } & 10 years & 19 & 31.7 \\
& & 11 and above & 24 & 40.0 \\
& \multirow{3}{*}{ Academic rank } & Professor & 7 & 11.7 \\
& & Associate Professor & 12 & 20.0 \\
& \multirow{2}{*}{ Total } & Assistant Professor & 41 & 68.3 \\
& & - & 60 & 100 \\
\hline
\end{tabular}

\section{Study Tool}

A questionnaire was used as the study tool, which was developed based on a theoretical framework derived from previous relevant studies. The developed questionnaire consisted of three parts: 
- The first part was designed to collect information about the characteristics of the study sample, namely the personal and functional variables (sex, years of experience and academic rank).

- The second part contained items covering the independent variable of the study (the reality of strategic planning).

- The third part contained items covering the dependent variable of the study (academic excellence).

A five-point Liker scale was used to measure the respondents' answers. The scores of the items were calculated as follows:Strongly agree (five points), agree (four points), neutral (three points), disagree (two points) and strongly disagree (one point).

Therefore, if the mean of an item was more than 3.67 this indicated that the level of perception was high. However, if the mean ranged from (2.34-3.67), the level of perception was medium. On the other hand, if the mean was less than 2.33 , the level of perception was low.

\subsection{Validity of the Study Tool}

The questionnaire was presented to (11) arbitrators form educational administration departments in Jordanian universities. In light of their views and observations, some of the items were reformulated and the required adjustments were made.

\subsection{Reliability of the study tool}

The reliability of the study tool was extracted using the (Cronbach's alpha) formula for internal consistency. If the Cronbach's alpha is high, this indicates that there is reliability and consistency between items. Table 3 shows the Cronbach's alpha values for the study variables.

Table 3.

\begin{tabular}{cc}
\hline Variable & Internal consistency using (Cronbach's alpha) \\
\hline Strategic planning & 0.89 \\
Academic excellence & 0.87 \\
Total & 0.91 \\
\hline
\end{tabular}

The results in Table 3 indicate that the coefficient of internal consistency for strategic planning was (0.89), while for academic excellence, was (0.87) and the total was (0.91). These values are acceptable for the purposes of this study. Note that an acceptable value for internal consistency is considered to be (0.70) and above (Sekaran, 2016).

\section{Results}

First question: What is the reality of strategic planning in the faculties of educational sciences in Jordanian private universities?

To answer the first question, the means, standard deviations, ranks and the level of the reality of strategic planning were calculated. The results are presented in Table 4. 
Table 4. Means, standard deviations, ranks and the level of the reality of strategic planning in the faculties of educational sciences in descending order of rank

\begin{tabular}{|c|c|c|c|c|c|}
\hline No & Item & Mean & $\begin{array}{l}\text { Standard } \\
\text { deviation }\end{array}$ & Rank & Level \\
\hline 1 & $\begin{array}{l}\text { The vision of the college is aimed at its growth and its } \\
\text { outlook for the future. }\end{array}$ & 3.95 & 0.92 & 1 & High \\
\hline 15 & $\begin{array}{l}\text { The college is committed to the budget specified in the } \\
\text { executive plan. }\end{array}$ & 3.85 & 0.96 & 2 & High \\
\hline 3 & The college's vision meets the needs of the labor market. & 3.82 & 0.95 & 3 & High \\
\hline 14 & $\begin{array}{c}\text { The college is committed to the timetables it sets for } \\
\text { achieving its objectives. }\end{array}$ & 3.81 & 0.93 & 4 & High \\
\hline 11 & $\begin{array}{l}\text { The college administration analyzes the internal } \\
\text { environment to identify strengths and weaknesses. }\end{array}$ & 3.77 & 0.99 & 5 & High \\
\hline 7 & $\begin{array}{l}\text { The organizational structure of the college fits in with the } \\
\text { nature of its work. }\end{array}$ & 3.76 & 0.93 & 6 & High \\
\hline 5 & The mission of the college includes its values and beliefs. & 3.75 & 0.96 & 7 & High \\
\hline 12 & $\begin{array}{l}\text { The college administration analyzes the external } \\
\text { environment to find out the different variables that can } \\
\text { affect it in the future. }\end{array}$ & 3.74 & 0.98 & 8 & High \\
\hline 8 & $\begin{array}{l}\text { The college determines the available and future } \\
\text { possibilities. }\end{array}$ & 3.73 & 0.98 & 9 & High \\
\hline 10 & $\begin{array}{l}\text { College administration encourages faculty members to } \\
\text { participate in the strategic planning of the college. }\end{array}$ & 3.72 & 0.55 & 10 & High \\
\hline 3 & $\begin{array}{c}\text { The college's vision meets its aspirations and } \\
\text { orientations. }\end{array}$ & 3.71 & 0.97 & 11 & High \\
\hline 9 & $\begin{array}{l}\text { The college uses experts from abroad to improve the } \\
\text { performance of faculty members in strategic planning. }\end{array}$ & 3.70 & 0.98 & 12 & High \\
\hline 4 & $\begin{array}{c}\text { The mission of the faculty deepens the integrated vision } \\
\text { among faculty members. }\end{array}$ & 3.69 & 1.01 & 13 & High \\
\hline 6 & The objectives of the college are realistic and measurable. & 3.68 & 0.98 & 14 & High \\
\hline 16 & $\begin{array}{l}\text { The college works in coordination and communication } \\
\text { with local community institutions. }\end{array}$ & 3.67 & 0.99 & 15 & Medium \\
\hline 18 & $\begin{array}{l}\text { The college applies clear performance criteria and } \\
\text { indicators to judge the plan. }\end{array}$ & 3.62 & 1.02 & 16 & Medium \\
\hline 17 & $\begin{array}{l}\text { The college oversees the means of implementing the } \\
\text { strategic plan. }\end{array}$ & 3.60 & 1.03 & 17 & Medium \\
\hline \multirow[t]{2}{*}{13} & $\begin{array}{l}\text { College administration face threats and opportunities as } \\
\text { an essential element of strategic planning. }\end{array}$ & 3.59 & 1.04 & 18 & Medium \\
\hline & Total Score & 3.73 & .53 & - & High \\
\hline
\end{tabular}

Table 4 indicates that the level of the reality of strategic planning in Jordanian private universities was high as the overall mean was (3.73) with a standard deviation of (0.53). Item (1), which states " that vision of the college is aimed at its growth and its outlook for the future", was ranked first with a mean of (3.95) and a standard deviation of (0.92). On the other hand, item (13), which states that" college administration face threats and opportunities as an essential element of strategic planning", had the lowest ranking with a mean of (3.59) and a standard deviation of (1.04). 
Second question: What is the level of achieving academic excellence in Jordanian private universities?

To answer the second question, the means, standard deviations, ranks and the level of achieving academic excellence were calculated. The results are shown in Table 5.

Table 5. Means, standard deviations, ranks and the level of achieving academic excellence in the faculties of educational sciences in descending order of rank

\begin{tabular}{|c|c|c|c|c|c|}
\hline No & Item & Mean & $\begin{array}{l}\text { Standard } \\
\text { deviation }\end{array}$ & Rank & Leve \\
\hline 24 & $\begin{array}{l}\text { The college has new courses related to excellence (Total } \\
\text { quality management, educational technology and modern } \\
\text { skills). }\end{array}$ & 3.94 & 0.88 & 1 & High \\
\hline 30 & $\begin{array}{l}\text { The college regularly and continuously reviews its plans } \\
\text { and programs. }\end{array}$ & 3.91 & 0.94 & 2 & High \\
\hline 22 & $\begin{array}{l}\text { The college encourages faculty members to publish in } \\
\text { international scientific journals. }\end{array}$ & 3.88 & 0.92 & 3 & High \\
\hline 23 & $\begin{array}{l}\text { The college is keen to hold periodic specialized scientific } \\
\text { conferences. }\end{array}$ & 3.86 & 0.93 & 4 & High \\
\hline 6 & $\begin{array}{l}\text { College administration enhances the role of strategic } \\
\text { planning at all levels of the organizational structure. }\end{array}$ & 3.85 & 0.95 & 5 & High \\
\hline 14 & $\begin{array}{c}\text { The college is keen to take advantage of technological } \\
\text { innovations. }\end{array}$ & 3.83 & 0.91 & 6 & High \\
\hline 4 & $\begin{array}{l}\text { Upon acceptance, the college takes into account the ratio } \\
\text { of students to faculty members. }\end{array}$ & 3.82 & 0.92 & 7 & High \\
\hline 17 & $\begin{array}{c}\text { The college adjusts study plans according to local market } \\
\text { requirements. }\end{array}$ & 3.81 & 0.92 & 8 & High \\
\hline 26 & $\begin{array}{l}\text { The college encourages faculty members to provide } \\
\text { developmental ideas. }\end{array}$ & 3.80 & 0.94 & 9 & High \\
\hline 21 & $\begin{array}{l}\text { The college uses an effective program to integrate new } \\
\text { faculty members into the work. }\end{array}$ & 3.79 & 0.96 & 10 & High \\
\hline 16 & $\begin{array}{c}\text { The college provides modern tools and references for } \\
\text { courses. }\end{array}$ & 3.78 & 0.96 & 11 & High \\
\hline 10 & $\begin{array}{l}\text { The diversity of college in the classification evaluation for } \\
\text { faculty members. }\end{array}$ & 3.76 & 0.93 & 13 & High \\
\hline 19 & $\begin{array}{l}\text { There are specialized committees in the college to } \\
\text { accomplish daily tasks. }\end{array}$ & 3.75 & 0.96 & 14 & High \\
\hline 7 & The college adopts a team spirit philosophy. & 3.74 & 0.96 & 15 & High \\
\hline 2 & $\begin{array}{l}\text { The college administration attracts highly qualified } \\
\text { persons to work in it. }\end{array}$ & 3.73 & 0.95 & 16 & High \\
\hline 18 & The college offers modern technology in classrooms. & 3.72 & 0.99 & 17 & High \\
\hline 3 & $\begin{array}{l}\text { The college is keen to promote the continuous } \\
\text { development of staff through holding seminars, } \\
\text { workshops and hosting experts. }\end{array}$ & 3.71 & 0.99 & 18 & High \\
\hline 11 & $\begin{array}{l}\text { The college conducts analytical studies of the needs of the } \\
\text { local community. }\end{array}$ & 3.70 & 0.98 & 19 & High \\
\hline 5 & $\begin{array}{l}\text { The college will conduct a comprehensive study to know } \\
\text { what is it needed to form the academic programs prior to }\end{array}$ & 3.69 & 1.00 & 20 & High \\
\hline
\end{tabular}


releases.

The college seeks to achieve a good competitive position

31 by obtaining internal and external credits such as: ISO and quality assurance certification.

The performance of the college is compared with its counterparts from other universities.

The college sets scientific standards to measure the actual performance of different operations.

The college allocates a special budget for employees to carry out social activities.

3.68

3.65

3.64

The college encourages faculty members to provide

feedback to improve the level of services offered to them.

The college provides electronic systems to ensure speed in the completion of operations.

The college is interested in providing specialized courses that aim at introducing employees to the importance of excellence in their work.

The college has cooperation agreements with other parties to train its students.

The college is constantly updating the means of information preservation.

The college offers opportunities for scholarships to its graduate students.

The college communicates with graduates effectively through employers and social media.

The college's administration develops the spirit of delegation among its staff.

The college adopts the principle of reward and punishment based on the performance evaluation form.

The college seeks to adopt the philosophy of change management.

The college seeks to achieve job satisfaction for its employees.

Total Score
3.63

3.61

3.58

3.59

3.52

3.50

3.44

3.42

68

0.96

$21 \quad$ High

1.01

1.01

22 Medium

1.04

23 Medium

0.99

$24 \quad$ Medium

0.99

$25 \quad$ Medium

1.04

27 Medium

$1.06 \quad 28 \quad$ Medium

1.05

$29 \quad$ Medium

1.02

30

Medium

1.06

31

Medium

1.07

32

Medium

1.02

33

Medium

1.07

34

Medium

1.08

35

Medium

3.69

0.56

High

Table 5 indicates that the level of achievement of academic excellence in Jordanian private universities was high as the overall mean was (3.69) with a standard deviation of (0.56). Item (24), which states "The college has new courses related to excellence (total quality management, educational technology, and modern skills)", was ranked first with a mean of (3.95) and a standard deviation of (0.88), with a high degree. On the other hand, item (28), which states 'The college seeks to achieve job satisfaction for its employees' was ranked last, with a mean of (3.38) and a standard deviation of (1.08), with a medium degree.

Third question:_Is there a significant relationship at $(\alpha \leq 0.05)$ between the reality of strategic planning and academic excellence in the Jordanian private universities?

To answer this question, Pearson's correlation coefficient was used. The value of Pearson's correlation coefficient was (0.73). Thus the result indicated that there was a positive and significant correlational relationship at $(\alpha \leq 0.05)$ between the level of the reality of strategic planning and academic excellence in the Jordanian private universities. 


\section{Discussion of Results}

\subsection{Discussion of the Results Related to the First Question}

The results in Table 4 indicated that the reality of strategic planning in Jordanian private universities were high. The researcher attributes this finding to the determined required skills that are available during the development of skills, experience, and knowledge of faculty members to reach a state of cognitive equilibrium that provides them with the necessary skills to improve the level of strategic planning and its components. The results also show the importance of hiring specialists and consultants in a proper way; to meet the needs of universities and faculty members. This may be due to the importance of strategic planning elements, which are considered as an important tool to achieve academic excellence. This is because of the importance of establishing the future orientation of the university and the goals it seeks to achieve, by enhancing organizational capabilities and enabling faculty members to acquire skills and information, so that they are able to cope with current and future challenges. It also suggests that repair is needed to bring about change and development in order to improve the performance of individuals at work and encourage them to make as much effort as possible, as well as led them to achieve the success by providing valuable information to students commensurate with the needs of the labour market. The results also showed that there is a need to have effective communication for the dissemination and transfer of information to all employees, on future trends, desired goals, and that it is important to exchange views on alternative plans.

These results are in agreement with the conclusion reported in Shablaq (2006), Al-Sanei (2013), Marzouga (2014) and Abu Hassanah(2016).

\subsection{Discussion of the Results Related to the Second Question}

The results in Table (5) indicated that the level of academic excellence in Jordanian private universities were high. This finding suggests that for private universities to ensure their survival and continuity they should not only focus on their level of efficiency, but also on change, development and renewal as these are the main features that have a strong influence on service quality and performance. Academic excellence is one of the indicators of the existence of cooperation and harmony between faculty members and administration. A high level of cooperation allows the opportunity to grow and develop to achieve individual ambitions and improve working methods. It can also help to ensure the utilization of the potential of the staff of the organization to achieve the interests of both the university and the individual.

\subsection{Discussion of the Results Related to the Third Question}

A positive and significant correlational relationship at $(\alpha \leq 0.05)$ was found between the level of the reality of strategic planning and academic excellence in Jordanian private universities. This finding implies that the availability of strategic planning elements leads to these institutions having organisational health. The existence of these elements in university is the strong belief by the university administration that they need to achieve the university goals and values. They also have the desire to make more effort and to give to the university in which they work to continue membership. This may be due to the fact that university administrations play a leading role in coordination and unifying efforts to achieve the university's goals. They do this through employing teams that are highly capable of developing and improving work processes. This result also suggests that university administrations possess certain mental abilities and creative abilities that help them to overcome the obstacles they face without complaining, and to encourage others to participate effectively in the organization, which then promotes academic excellence.

\section{Recommendations}

In light of the results of this study, the following recommendations are made:

1. There is a need to provide an organizational climate in Jordanian private universities to help them achieve organizational health and academic excellence through:

- Holding training courses for faculty members at the university to impart knowledge on the concept of strategic planning, so that it can be applied in a proper manner;

- Developing comprehensive strategies based on the best practices of the elements of strategic planning by providing the appropriate climate and supporting the teamwork of various teams and giving due attention to the interests of employees;

- Limiting as much as possible the obstacles that stand in the way of achieving academic excellence and benefit from the correlation and reflection of the management of excellence in the university performance in line with the needs of the local community and the labour market; 
- Providing rewards to distinguished teaching staff at Jordanian private universities and commending them for their efforts.

2. There is a need to benefit from the experiences of other countries on the subject of standards of academic excellence and to enhance the positive effects of their experiences and the downsizing of these experiments while taking into consideration the specificity of the Jordanian environment.

3. There is a need to initiate an organizational culture within Jordanian private universities that is, based on the elements of strategic planning and academic excellence, and to crystallize values that reflect the concepts of participation, cooperation, teamwork and diversity of skills.

4. Lastly, it should be noted that this study did not cover all the dimensions related to strategic planning in universities. It has kept the field open for further studies to investigate other dimensions related to the variables of interest to this study, such as: knowledge management, information technology, transformational leadership and total quality management.

\section{References}

Al-Hadabi, D.A. \& Kashwa, H.A. (2009). Quality of educational service in Hoja, from students' of scientific department's point of view. Arab Journal for Quality Assurance of University Education, No. 4.

Al-Hilalat, S.A.O. (2014). Excellence management: Modern practice in the management of business organizations, 1st ed., Amman: Dar Wa'el for Publishing and Distribution.

Al-Salami, A. (2001). Organization theory. Cairo: Dar Gareeb for Printing.

Al-Sanie, K.H.A. (2013). The degree of practice of the deans of the intermediate university colleges in the middle governorates of strategic planning and its relation to the level of quality assurance (Unpublished Master Thesis).The Middle East University, Amman, Jordan.

Al-Shuwaikh, A. (2007). The reality of strategic planning in the institutions of technical education in the governorates of Gaza (Unpublished Master Thesis), Islamic University, Gaza, Palestine.

Davies, B. (2007). From school development to a strategic planning framework. Retrieved from http://www.ncsl.org.uk/media/f7b/kpool-evidence-davies.pdf.

Defifo, S. (2008). The strategic planning process: An analysis at two small colleges (A Doctorate Dissertation), University of Pennsylvania, Pennsylvania, USA.

Dijani, I. (2006). Reality of strategic Planning at IUG according to quality criteria (Unpublished Master Thesis), Islamic University, Gaza, Palestine.

Killen, P. \& Walker, R. (2007). Strategic using quality function development. International Journal of Quality \& Reability Management, 22(1), 17-29. https://doi.org/10.1108/02656710510572968

Marzouka, H. (2014). The impact of strategic planning for total quality management in improving the performance of employees in private universities in Jordan (Unpublished Master Thesis), The Middle East University, Amman, Jordan.

Ministry of higher education and scientific research. (2010). National Conference for the Reform of Higher Education, for the period from 23 to 29 March, 2010, Arbil, Iraq.

Petrides, L. (2003). Strategic and information use: The role of institutional leadership in the community colleges. On the Horizon Journal, 11(4), 10-14. https://doi.org/10.1108/10748120310508037 